\title{
Combining combing and secondary ion mass spectrometry to study DNA on chips using ${ }^{13} \mathrm{C}$ and ${ }^{15} \mathrm{~N}$ labeling [version 1; peer
}

\section{review: 2 approved]}

\author{
Armelle Cabin-Flaman ${ }^{1}$, Anne-Francoise Monnier ${ }^{1}$, Yannick Coffinier ${ }^{2}$, \\ Jean-Nicolas Audinot (id) 3 , David Gibouin'1, Tom Wirtz³ , Rabah Boukherroub², \\ Henri-Noël Migeon ${ }^{3}$, Aaron Bensimon ${ }^{4}$, Laurent Jannière ${ }^{5}$, Camille Ripoll1, \\ Victor Norris 6
}

\footnotetext{
${ }^{1}$ Equipe AMMIS, laboratoire MERCI EA 3829, faculté des Sciences et Techniques, University of Rouen, Mont-Saint-Aignan Cedex, France

2Institute of Electronics, Microelectronics and Nanotechnology (IEMN), UMR CNRS 8520, Lille1 University, Villeneuve d'Ascq, France ${ }^{3}$ Material Research \& Technology Department (MRT), Luxembourg Institute of Science and Technology (LIST), Belvaux, Luxembourg ${ }^{4}$ Genomic Vision, Bagneux, France

5 iSSB, Génopole, CNRS, UEVE, Université Paris-Saclay, Evry, France

${ }^{6}$ Laboratory Microbiology Signals and Environment EA4312, Department of Biology, University of Rouen, Mont-Saint-Aignan Cedex, France
}

\section{V1 First published: 20 Jun 2016, 5:1437 \\ https://doi.org/10.12688/f1000research.8361.1 \\ Latest published: 20 Jun 2016, 5:1437 \\ https://doi.org/10.12688/f1000research.8361.1}

\section{Abstract}

Dynamic secondary ion mass spectrometry (D-SIMS) imaging of combed DNA - the combing, imaging by SIMS or CIS method - has been developed previously using a standard NanoSIMS 50 to reveal, on the $50 \mathrm{~nm}$ scale, individual DNA fibers labeled with different, nonradioactive isotopes in vivo and to quantify these isotopes. This makes CIS especially suitable for determining the times, places and rates of DNA synthesis as well as the detection of the fine-scale rearrangements of DNA and of molecules associated with combed DNA fibers. Here, we show how CIS may be extended to ${ }^{13} \mathrm{C}$-labeling via the detection and quantification of the ${ }^{13} \mathrm{C}^{14} \mathrm{~N}^{-}$recombinant ion and the use of the ${ }^{13} \mathrm{C}:{ }^{12} \mathrm{C}$ ratio, we discuss how CIS might permit three successive labels, and we suggest ideas that might be explored using CIS.

\section{Keywords}

DNA isotope labeling, PCR, DNA extraction, silicon chip, surface coating, isotope recombination

\section{Open Peer Review}

Approval Status

1 2

version 1

20 Jun 2016
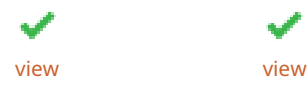

1. Bruno Fabre, University of Rennes 1, Rennes, France

2. Freddy C. Adams, University of Antwerp, Antwerp, Belgium

Any reports and responses or comments on the article can be found at the end of the article. 
Corresponding author: Victor Norris (Victor.Norris@univ-rouen.fr)

Competing interests: The Luxembourg Institute of Science and Technology markets cesium-flooding equipment. Genomic Vision offers a DNA-combing service.

Grant information: This work was partly supported by the FP7 EU Network of Excellence, Nanobeams n500440 to Henri-Noël Migeon. The funders had no role in study design, data collection and analysis, decision to publish, or preparation of the manuscript.

Copyright: @ 2016 Cabin-Flaman A et al. This is an open access article distributed under the terms of the Creative Commons Attribution License, which permits unrestricted use, distribution, and reproduction in any medium, provided the original work is properly cited. Data associated with the article are available under the terms of the Creative Commons Zero "No rights reserved" data waiver (CC0 1.0 Public domain dedication).

How to cite this article: Cabin-Flaman A, Monnier AF, Coffinier $Y$ et al. Combining combing and secondary ion mass spectrometry to study DNA on chips using ${ }^{13} \mathrm{C}$ and ${ }^{15} \mathrm{~N}$ labeling [version 1; peer review: 2 approved] F1000Research 2016, 5:1437 https://doi.org/10.12688/f1000research.8361.1

First published: 20 Jun 2016, 5:1437 https://doi.org/10.12688/f1000research.8361.1 


\section{Introduction}

The CIS method (for combing-imaging by SIMS) combines DNA combing on a silicon surface, flooding the surface with cesium, and the sensitive imaging technique of dynamic secondary ion mass spectrometry (D-SIMS) as provided by a Cameca NanoSIMS 50, a machine that allows five or seven different masses to be detected simultaneously, depending on the version ${ }^{1,2}$. This method may be of interest for those who wish to obtain fine-scale, quantitative information on DNA replication and protein-DNA interactions at the level of single molecules without the need to modify these molecules. Previously, we have used the CIS method and a NanoSIMS 50 to obtain quantitative images of single DNA fibers combed on modified, SIMS-compatible, silicon surfaces with lengths similar to those expected for the B-conformation and with a resolution of $50 \mathrm{~nm}$, i.e., $150 \mathrm{bp}^{3}$.

Variations in the rates and/or directions of DNA synthesis are implicated in many processes, including gene expression ${ }^{4}$, nutrient sensing involving the alarmone (p)ppgpp ${ }^{5}$, R-loop-mediated replication $^{6}$ and DNA repair ${ }^{7}$. Variations between replisomes within the same chromosome have been observed using BrdU and light microscopy ${ }^{8}$. To study such variations on the $50 \mathrm{~nm}$ scale, CIS might usefully be extended to image not only the ${ }^{12} \mathrm{C}^{15} \mathrm{~N}^{-}$and ${ }^{13} \mathrm{C}^{15} \mathrm{~N}^{-}$recombinant ions but also other ions. Here, we describe in detail the protocols needed for CIS, we report using CIS to image the ${ }^{13} \mathrm{C}$, we suggest ways in which ${ }^{13} \mathrm{C}$-imaging could be improved, and we mention possible applications.

\section{Materials and methods}

Preparation of DNA

In principle, DNA could be extracted from any organism to perform CIS. DNA generated in vitro can also be used. For the experiment reported here, for example, we extracted DNA from the 168 (trpC2) strain of Bacillus subtilis and a derivative (MT119, trpC2 leuB6 $r$ - m-) harboring a $21.1 \mathrm{~kb}$ long, chloramphenicolresistant plasmid (pHV1431 plus insert of $10.3 \mathrm{~kb})^{3}$. On modified silicon surfaces at concentrations of $0.2 \mu \mathrm{g} / \mathrm{mL}$, most of the DNA is combed as single fibers. Higher concentrations can lead to fibers running together whilst lower concentrations result in an insufficient number of fibers on the images. Combing works well with buffers containing $\mathrm{NaCl}$ at ionic strengths of around $0.2 \mathrm{M}$.

Bacterial culture medium: $14 \mathrm{~g} / \mathrm{L}$ of $\mathrm{K}_{2} \mathrm{HPO}_{4}, 6 \mathrm{~g} / \mathrm{L}$ of $\mathrm{KH}_{2} \mathrm{PO}_{4}$, $1 \mathrm{~g} / \mathrm{L}$ of sodium citrate, $10 \mathrm{mM} \mathrm{MgSO}_{4}, 0.01 \%$ (w/v) of tryptophan, $0.005 \%(\mathrm{w} / \mathrm{v})$ of leucine, $0.2 \%(\mathrm{w} / \mathrm{v})$ of ${ }^{13} \mathrm{C}$-glucose (Isotec) and $0.8 \mathrm{~g} / \mathrm{L}$ of ${ }^{15} \mathrm{NH}_{4} \mathrm{Cl}$ (Isotec). Lysis buffer: $50 \mathrm{mM}$ of Tris- $\mathrm{HCl}$ (pH8.0), 10mM of EDTA (pH8.0), 150mM of NaCl and $5 \mathrm{mg} / \mathrm{ml}$ of lysozyme. Proteinase K: Final concentration of $0.2 \mathrm{mg} / \mathrm{mL}$ (Roche). Sarcosyl Buffer: Final concentration of 1.2\%. Phenol/chloroform: Solution PCI: phenol-chloroform-isoamylalcohol (25:24:1 v/v) (the phenol is first saturated in $\mathrm{NaCl} 150 \mathrm{mM}$ and buffered at $\mathrm{pH}$ of about 7); Solution CI: chloroform-isoamylalcohol (24:1 v/v). RNase: Final concentration of $20 \mu \mathrm{g} / \mathrm{mL}$ (Roche).

Other materials required are: $100 \%$ cold ethanol; $70 \%$ (v/v) ethanol; $\mathrm{NaCl}$ solution: $0.2 \mathrm{M}$ to $1 \mathrm{M}$; PureYield ${ }^{\mathrm{TM}}$ plasmid midiprep system (Promega); restriction enzyme; 0.3M Potassium acetate pH7.0;
TaKaRa EX Taq ${ }^{\text {TM }}$ system (TaKaRa); Expand Long Template PCR System (Roche Applied Science); QIAquick PCR Purification kit (QIAGEN).

DNA preparation from bacterial cultures. DNA can be prepared from any cells using a procedure that removes contaminating peptide and RNA molecules. In the case of the labeling and extraction of B. subtilis DNA, B. subtilis cells were cultivated at $30-37^{\circ} \mathrm{C}$ for 20 generations in bacterial culture medium containing stable isotopes (here, ${ }^{13} \mathrm{C}$ and ${ }^{15} \mathrm{~N}$, see above) to saturation. Then, to prepare chromosomal DNA free of peptides and RNA, one milliliter of a freshly saturated culture was centrifuged at $15000 \mathrm{~g}$ for $2 \mathrm{~min}$ at $4^{\circ} \mathrm{C}$. The supernatant was discarded. Pelleted cells were resuspended in $0.5 \mathrm{~mL}$ of lysis buffer. The cell resuspension was incubated for 20 minutes at $37^{\circ} \mathrm{C}$. Proteinase $\mathrm{K}$ was added to a final concentration of $0.2 \mathrm{mg} / \mathrm{mL}$ in addition to $20 \mu \mathrm{L}$ of sarcosyl buffer $30 \%(1.2 \%$, final concentration) and incubated for 20 $\min$ at $65^{\circ} \mathrm{C}$. To remove peptides and cell fragments by a phenol/chloroform treatment, we lowered the temperature of the sample on ice for $3 \mathrm{~min}$ and then added $500 \mu \mathrm{L}$ of solution PCI (see Preparation of DNA) at $4^{\circ} \mathrm{C}$ and vortexed strongly for $30 \mathrm{~s}$. The mixture was centrifuged at $15000 \mathrm{~g}$ for $15 \mathrm{~min}$ at room temperature in a benchtop centrifuge. The aqueous solution was recovered and $500 \mu \mathrm{L}$ of solution CI was added to it (see Preparation of DNA). This mixture was vortexed strongly and centrifuged as above. RNase was added to a final concentration of $20 \mu \mathrm{g} / \mathrm{mL}$ to the aqueous, nucleic acid-containing phase and incubated for $10 \mathrm{~min}$ at $37^{\circ} \mathrm{C}$. DNA was purified by a second phenol/chloroform extraction as above. We added 2.2 volume of $100 \%-20^{\circ} \mathrm{C}$ ethanol to the aqueous solution and centrifuged at $15000 \mathrm{~g}$ for $20 \mathrm{~min}$ at $4^{\circ} \mathrm{C}$ in a benchtop centrifuge. The supernatant was discarded and the DNA pellet was washed in $70 \%$ cold ethanol. This mixture was centrifuged again for $10 \mathrm{~min}$ at $4{ }^{\circ} \mathrm{C}$ at $15000 \mathrm{~g}$ and the supernatant was discarded. The DNA pellet was dried for $10 \mathrm{~min}$ under vacuum and resuspended carefully in pure water for at least $12 \mathrm{~h}$ at room temperature (note that incomplete solubilization of ethanol-precipitated DNA severely perturbs combing). DNA concentration was measured by absorbance at 260/280 $\mathrm{nm}$ using a Nanodrop 2000 (Thermo Scientific). Depending on the fragment length, DNA concentration should be adjusted to within the range 0.2 to $2 \mu \mathrm{g} / \mathrm{mL}$ by dilution in $\mathrm{NaCl}$ solutions that may range up to to $1 \mathrm{M}$; here, we used DNA at $0.2 \mu \mathrm{g} / \mathrm{mL}$ in $0.2 \mathrm{M} \mathrm{NaCl}$.

In this paper, we only report CIS in the case of chromosomal DNA. CIS can also be used to analyse plasmid DNA (not shown). In the case, for example, of a $20 \mathrm{~kb}$ plasmid from B. subtilis, plasmid DNA may be extracted using the PureYieldTM plasmid midiprep system (Promega Corporation, Madison, WI, USA), followed by linearization of the plasmid by a single cutter restriction enzyme according to suppliers' instructions (e.g. New England BioLabs, Inc., Hitchin, UK) to give fragments of the appropriate size; this linearization is needed before combing because of the difficulty of combing supercoiled circular molecules. After linearization, the DNA can be purified by the phenol/chloroform procedure and recovered by ethanol precipitation in the presence of $0.3 \mathrm{M}$ potassium acetate $\mathrm{pH} 7$. 
DNA preparation by PCR (protocol used to prepare PCRgenerated DNA fragments 1-20 kb long). DNA fragments generated by PCR can be analyzed by CIS $^{3}$. We routinely produce fragments $<5 \mathrm{~kb}$ using the TaKaRa Ex $\mathrm{Taq}^{\mathrm{TM}}$ system (Takara Shuzo Co., Ltd, Shiga, Japan). For products of 5-20 kb, we use the Expand Long Template PCR System from Roche Applied Science (Mannheim, Germany). The PCR products can be purified with the QIAquick PCR Purification kit (QIAGEN GmbH, Hilden, Germany). PCR products can then be diluted for CIS as described above.

\section{Preparation of silicon surfaces}

This experiment required an efficient fume hood. The materials used were: P-type 100 crystalline silicon wafers (Siltronix) with a resistivity $>1 \Omega \mathrm{cm}$ (typically $10 \mathrm{~mm} \times 10 \mathrm{~mm} \times 380 \mu \mathrm{m}$ ); Piranha solution obtained by mixing 3 volumes of $96 \%$ of sulfuric acid [VLSI (very large-scale integration)-grade] and 1 volume of $30 \%$ hydrogen peroxide (VLSI-grade), to be used immediately; $50 \%$ hydrofluoric acid (VLSI-grade); acetone; isopropyl alcohol $(i \mathrm{PrOH})$; chloroform $\left(\mathrm{CHCl}_{3}\right)$; ethanol $(\mathrm{EtOH})$; 1-tetradecene; a photochemical reactor for UV irradiation $(\lambda=312 \mathrm{~nm}$ ) (our home-made reactor has 8 tubes in a circle around a Schlenk tube with a fan at the bottom to limit any increase in temperature); a goniometer system (DIGIDROP, GBX, France).

Preparation of hydrogenated-terminated silicon surfaces. In the following preparation, it should be noted that the piranha solution is a powerful oxidant that reacts violently with organic materials; it can cause serious skin burns and must be handled with great care in a well-ventilated fume hood while wearing appropriate chemical safety protection. Moreover, HF is a hazardous acid that can cause severe damage to tissues if burns are not treated properly. Etching of silicon should therefore be carried out in a fume hood with the right safety measures, which include a face shield and double-layered nitrile gloves.

The silicon surface was cleaned in an ultrasonic bath for $5 \mathrm{~min}$ periods in acetone and isopropylic alcohol. It was then rinsed extensively with ultrapure water and immersed for $20 \mathrm{~min}$ in a piranha solution to remove organic contaminants on the surface. This was followed by the immersion of the clean surface in an aqueous solution of $\mathrm{HF}$ (50\%, as provided by the supplier) to generate a hydrogen-terminated surface $(\mathrm{Si}-\mathrm{H})^{9}$. This surface was washed extensively with water and then dried by blowing with nitrogen. The resulting surface typically had a contact angle of $85^{\circ}$ for a $1 \mu \mathrm{L}$ water droplet. Note that freshly prepared $\mathrm{Si}-\mathrm{H}$ surfaces were used immediately for DNA combing or for grafting hydrocarbon chains (see below). Before combing, coated silicon surfaces were protected from dust and dried because a thin film of water greatly reduces DNA adsorption.

Formation of organic monolayers on hydrogen-terminated silicon surfaces. To obtain highly hydrophobic surfaces, alkenes with $\mathrm{C}_{14}$ alkyl chains were grafted onto freshly prepared $\mathrm{Si}-\mathrm{H}$ surfaces using the hydrosilylation reaction of 1-tetradecene with the hydrogen-terminated silicon surface ${ }^{9}$. The freshly hydrogenterminated silicon surface (see above) was immersed in a Schlenk tube containing $10 \mathrm{ml}$ of previously deoxygenated, neat 1-tetradecene under nitrogen bubbling. This was then irradiated at $312 \mathrm{~nm}$ in a photochemical reactor for $3 \mathrm{~h}$. We removed unreacted and physisorbed 1-tetradecene by rinsing with chloroform and ethanol at room temperature. The silicon substrate was dried under a stream of nitrogen. We verified that water contact angles (using deionized water in the ambient atmosphere at room temperature) are around $104^{\circ}$ as measured to an accuracy of $\pm 2^{\circ}$ with a remote, computer-controlled, goniometer system (N.B., protect the surface from dust, see above).

Combing on silicon. The 'drop' and 'lift' methods ${ }^{10,11}$ can both be used to comb DNA on the $\mathrm{Si}_{-} \mathrm{C}_{14}$ surface. Both 'drop' and 'lift' methods entail the DNA becoming attached to the surface and then drawn out and aligned perpendicular to the triple line or the meniscus, respectively. The 'drop' method entails depositing $10 \mu \mathrm{L}$ of prepared DNA solution on the silicon surface, incubating it for $10 \mathrm{~min}$ on the bench, tilting the surface with tweezers to $45^{\circ}$ to cause the drop to roll off the surface, and washing the surface by immersion in water and rapidly air-drying; the quality of combing via this method can be adversely affected by vibrations occurring during the movement of the drop. Here, we used the 'lift' method, which entails immersing a part of the silicon surface in a DNA solution (see above); after 5 min incubation, the silicon surface was pulled out of the solution at a constant speed $(600 \mu \mathrm{m} / \mathrm{min})$ and rapidly air-dried. In both 'drop' and 'lift' methods, washing the surfaces after combing helps avoid perturbation of D-SIMS analysis by saline crystals. The tightly controlled, motor-driven 'lift' method gives more reproducible, better quality results but takes longer and requires more DNA than the manual 'drop' method. The 'lift' method is better than the drop method for fragments less than $5 \mathrm{~kb}$; the 'drop' method is satisfactory with fragments equal to or greater than $5 \mathrm{~kb}$.

\section{D-SIMS methods}

Cs flooding method. To avoid a premature destruction of thin samples before SIMS detection ${ }^{12}$, a cesium flooding system is recommended to deposit neutral cesium on samples ${ }^{13,14}$. We used a UHV Cs evaporation system which is available for purchase from the Luxembourg Institute of Science and Technology (LIST). It comprises a neutral cesium evaporator and an independent standalone UHV chamber. A suitcase under UHV $\left(10^{-8}\right.$ to $10^{-10}$ Torr) was used to transfer samples to the NanoSIMS50 thereby avoiding an immediate reaction between the neutral cesium deposit and air. To analyze combed DNA (as performed here), we flooded the surface with $\mathrm{Cs}^{0}$ at $1.5 \AA / \mathrm{s}$ for $1800 \mathrm{~s}$ before SIMS imaging. An alternative to cesium flooding is to coat samples with $\mathrm{Au}$; a Cressington Sputter Coater can be used to deposit a layer of Au, approximately $60 \mathrm{~nm}$ thick, on wafers with combed DNA but the quality of the images subsequently obtained is often poor.

NanoSIMS 50 analyses. In SIMS analyses of samples labeled with carbon and nitrogen, there are several factors that should be borne in mind. First, carbon can be detected as $\mathrm{C}^{-}$and in multi-clusters that include $\mathrm{CN}^{-}$and $\mathrm{C}_{2}^{-}$(N.B. $\mathrm{CN}$ is easier to ionize and therefore detect than $\mathrm{C}_{\text {and }} \mathrm{C}_{2}$ because the electron affinity is $3.8 \mathrm{eV}$ for $\mathrm{CN}^{-}$, $1.26 \mathrm{eV}$ for $\mathrm{C}^{-}$and $3.27 \mathrm{eV}$ for $\mathrm{C}_{2}^{-}$). Second, nitrogen can be detected in the multi-cluster $\mathrm{CN}$ (note that nitrogen forms fewer types of multi-clusters thant carbon even though it can form to a very 
limited degree multi-clusters that include $\mathrm{NO}, \mathrm{N}_{2} \mathrm{H}$, and NS). Third, the probability of formation of the $\mathrm{CN}$ multi-cluster in the mixingrecombination under the primary beam is related to the distance between the carbon and nitrogen atoms ${ }^{15}$; this means that differentially labeled macromolecules can be colocalized if they are within $2 \mathrm{~nm}$ of one another; it also means that the carbon and nitrogen in the DNA are more likely to recombine with one another than with carbon and nitrogen that are further away. Note that even a trace amount of contaminants is an important problem for the highly sensitive CIS method and strenuous efforts should therefore be taken to protect samples from contamination by, for example, an atmosphere containing $\mathrm{C}$ and $\mathrm{N}$. Silicon surfaces with combed DNA were analyzed in the multi-collection image mode of the NanoSIMS 50 (Cameca, Gennevilliers, France). The NanoSIMS 50 was used in the negative secondary-ion mode with the $\mathrm{Cs}^{+}$primary ion beam. In this case high spatial resolution images were obtained using a primary beam around $0.5-1.0 \mathrm{pA}$ in intensity and an impact energy of $16 \mathrm{keV}$. The surface was rastered by the cesium beam on a surface from $5 \times 5$ to $15 \times 15 \mu \mathrm{m}^{2}$. The instrument was tuned to limit the dispersion in aperture and energy in order to obtain a minimal mass resolution of $\mathrm{M} / \Delta \mathrm{M}=5000$ ( $10 \%$ height peak measurement).

Aphelion 3.2 was used to analyze the results pixel by pixel or line by line, whilst ImageJ plus the OPEN MIMS plug-in (which opens the .im format ${ }^{16}$ and is available from http://www.nrims. harvard.edu) was used to analyze the data in an ROI (Region Of Interest). The data were summed and the images colored using WinImage 2. The images of the ${ }^{12} \mathrm{C}(\mathrm{m}=12.000000)$, and $/$ or ${ }^{13} \mathrm{C}$ $(\mathrm{m}=13.00335484),{ }^{12} \mathrm{C}^{14} \mathrm{~N}(\mathrm{~m}=26.003074),{ }^{12} \mathrm{C}^{15} \mathrm{~N}(\mathrm{~m}=27.00010898)$ or ${ }^{13} \mathrm{C}^{14} \mathrm{~N}(\mathrm{~m}=27.00642885),{ }^{13} \mathrm{C}^{15} \mathrm{~N}(\mathrm{~m}=28.00346382)$ were acquired simultaneously in $256 \times 256$ pixels with a dwell time of 10 ms per pixel. Note that ${ }^{12} \mathrm{C}^{15} \mathrm{~N}$ and ${ }^{13} \mathrm{C}^{14} \mathrm{~N}$ cannot be detected simultaneously in the same 'sputter section'. The sulfur ${ }^{32} \mathrm{~S}$ $(m=31.9720718)$ distribution can be also acquired to control the quality of the preparation.

\section{Results}

\section{Dataset 1. Raw data for Combing-Imaging by SIMS of bacterial} DNA

http://dx.doi.org/10.5256/f1000research.8361.d120278

Double-labeled (13C, 15N) chromosomal DNA from Bacillus subtilis was combed onto a silicon surface, analysed with a NanoSIMS 50 set to detect masses of 12, 13, 26, 27 and 28 for $12 \mathrm{C}-, 13 \mathrm{C}-, 12 \mathrm{C} 14 \mathrm{~N}-, 13 \mathrm{C} 14 \mathrm{~N}$ - and $13 \mathrm{C} 15 \mathrm{~N}$ - ions, respectively. The data were treated with Aphelion

The CIS technique reveals individual DNA fibers of a wide variety of lengths lying in parallel (Figure 1). These fibers are particularly clear in the ${ }^{13} \mathrm{C}^{15} \mathrm{~N}$ image of the DNA (Figure 1a) but, importantly, they can also be discerned in the ${ }^{13} \mathrm{C}^{14} \mathrm{~N}$ image (Figure $1 \mathrm{~b}$ ). The images differ because (1) the coating on the silicon surface contains a large amount of the natural isotopes of carbon of which $1 \%$ is ${ }^{13} \mathrm{C}$; this $1 \%$ can then recombine with contaminant nitrogen to generate a high background of ${ }^{13} \mathrm{C}^{14} \mathrm{~N}$ that partially masks the signal from the labeled DNA (even though this DNA is $99 \%{ }^{13} \mathrm{C}$ ) and (2) the background of ${ }^{13} \mathrm{C}^{15} \mathrm{~N}$ is low since this ion arises at a frequency of 1:25000 in combinations of naturally occurring carbon and nitrogen).

Most of the fibers have similar counts throughout their lengths but, in a couple of cases, two fibers overlap and this results in more ${ }^{13} \mathrm{C}^{15} \mathrm{~N}^{-}$recombinant ions being detected (the red stretches in Figure 1a). The relative constancy of the counts and the similarity between the calculated lengths of the DNA and the lengths estimated by SIMS support the claim that CIS does not stretch or condense DNA ${ }^{3}$. However, an exception to this may occur when the DNA is so short that it cannot be combed properly, as is probably the case of the red spots of a few nm (Figure 1a).

The fibers in the image of the isotope ratio ${ }^{13} \mathrm{C} /{ }^{12} \mathrm{C}$ image (Figure 1c) are difficult to detect in their entirety. One reason for this difficulty is that the natural carbon in the coating on the surface contains ${ }^{13} \mathrm{C}$, as mentioned above. A second reason is that the yield of carbon in the $\mathrm{C}^{-}$form is relatively low and therefore the ratio can fluctuate (see Materials and methods). A third reason is that the carbon in the DNA reacts with neighboring atoms in the DNA (and elsewhere) such as nitrogen - and indeed carbon itself - to give multi-clusters (see Materials and methods); this means that much of the ${ }^{13} \mathrm{C}$ is being distributed into multi-clusters that include ${ }^{13} \mathrm{C}^{15} \mathrm{~N},{ }^{13} \mathrm{C}^{14} \mathrm{~N},{ }^{12} \mathrm{C}^{13} \mathrm{C}$ and ${ }^{13} \mathrm{C}^{13} \mathrm{C}$. It is therefore significant that, even in these unfavorable conditions for detecting ${ }^{13} \mathrm{C}$ via the ${ }^{13} \mathrm{C}:{ }^{12} \mathrm{C}$ ratio, ${ }^{13} \mathrm{C}$-labeled fibers can just about be distinguished (Figure 1c).

In the experiment reported here, $98 \%$ of the nitrogen in the DNA is ${ }^{15} \mathrm{~N}$. This means that the counts of ${ }^{13} \mathrm{C}^{14} \mathrm{~N}$ coming from recombination between the atoms within the DNA are nearly $98 \%$ lower than they would be if all the nitrogen in the DNA were present as the ${ }^{14} \mathrm{~N}$ isotope. To answer the question of whether labeling with ${ }^{13} \mathrm{C}$ alone (i.e., without ${ }^{15} \mathrm{~N}$-labeling) is sufficient to allow DNA to be detected, we added the counts of ${ }^{13} \mathrm{C}^{15} \mathrm{~N}$ (Figure 1a) to those of ${ }^{13} \mathrm{C}^{14} \mathrm{~N}$ (Figure 1b) to obtain an image of ${ }^{13} \mathrm{CN}$ (Figure 1d). The fibers are again clear, showing that ${ }^{13} \mathrm{C}$ labeling is indeed sufficient to allow DNA to be detected.

\section{Discussion}

Previously, we have suggested that CIS could be used in conjunction with pulse-labeling with different isotopes to identify origins of replication or to study local variations in the rate of DNA elongation resulting from signals generated inside or outside cells or from addition of drugs ${ }^{3}$. Such pulse-labeling can be readily based on ${ }^{15} \mathrm{~N}$ since this is relatively rare naturally $(0.36 \%)$ and enriching in ${ }^{15} \mathrm{~N}$ therefore makes fibers readily detectable. Here, we ask whether ${ }^{13} \mathrm{C}$ labeling with ${ }^{13} \mathrm{C}$ alone might suffice for detection via CIS. We try to answer this question in the context of having labeled the fibers with both ${ }^{13} \mathrm{C}$ and ${ }^{15} \mathrm{~N}$ (Figure 1a). Even in these conditions, the image of the ${ }^{13} \mathrm{C}^{14} \mathrm{~N}^{-}$recombinant ion does allow fibers to be discerned, albeit with difficulty (Figure 1b). This difficulty is due not only to reduction of the ratio by surface contamination by carbon (which contains $1 \%{ }^{13} \mathrm{C}$ ) but also to the recombination that generates multi-clusters (see Materials and methods); the latter includes recombination between the ${ }^{13} \mathrm{C}$ and ${ }^{15} \mathrm{~N}$ in the fibers to give ${ }^{13} \mathrm{C}^{15} \mathrm{~N}$ (it is therefore not surprising that the fibers are hard to 

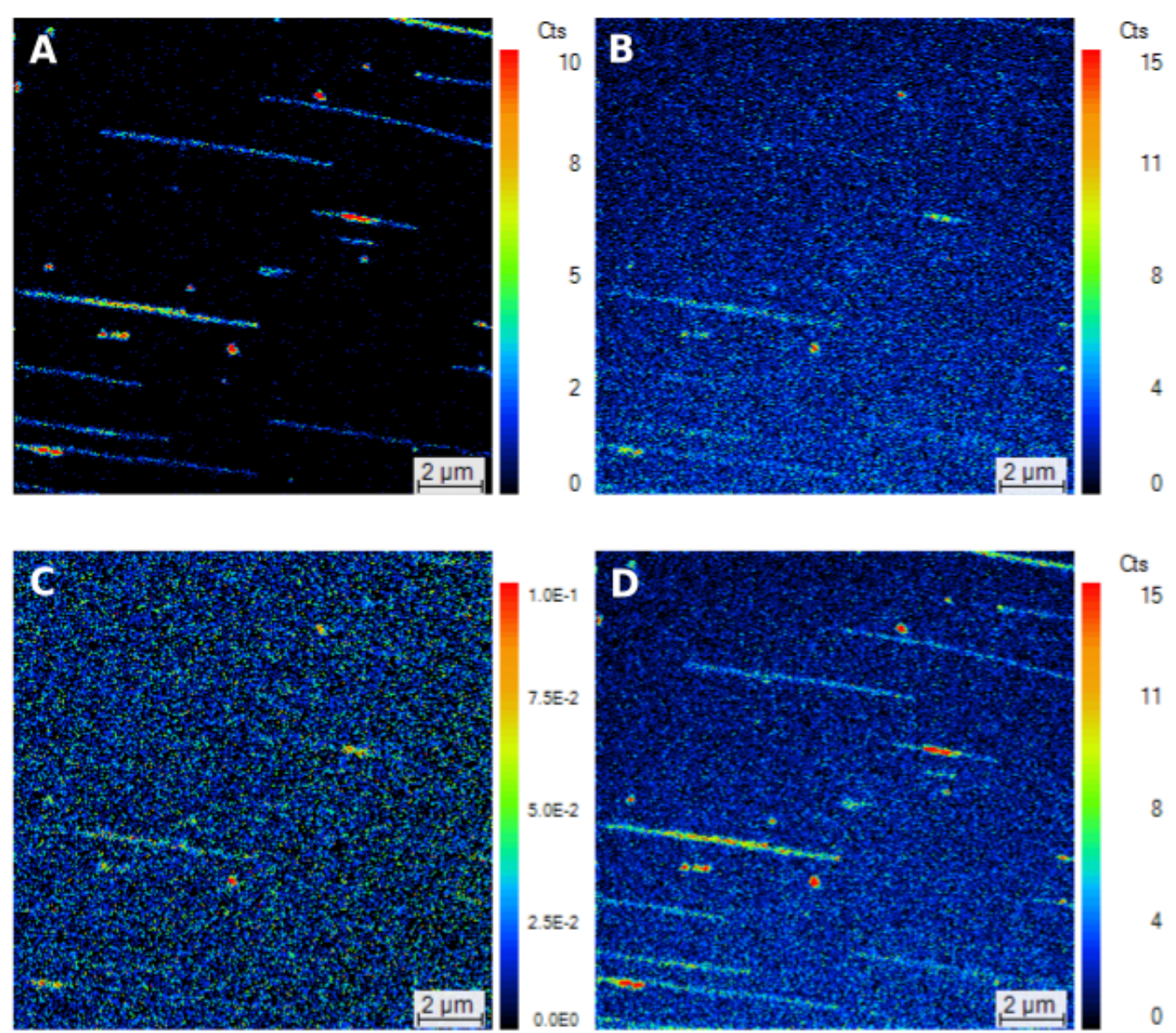

Figure 1. SIMS images of double-labeled $\left({ }^{13} \mathbf{C},{ }^{15} \mathrm{~N}\right)$ chromosomal Bacillus subtilis DNA. The DNA was combed at $0.2 \mu \mathrm{g} / \mathrm{mL}$ on a Si_C 14 wafer using the lift method, the wafer surface was covered with cesium and analyzed with a NanoSIMS 50. Primary beam intensity, 1 pA; dwell time, $30 \mathrm{~ms}$; field of view, $15 \mu \mathrm{m} \times 15 \mu \mathrm{m}$; $256 \times 256$ pixels; scale bar $=1 \mu \mathrm{m}$. $(\mathbf{a}){ }^{13} \mathrm{C}{ }^{15} \mathrm{~N},(\mathbf{b}){ }^{13} \mathrm{C}{ }^{14} \mathrm{~N}$, $(\mathbf{c})$ Isotope ratio ${ }^{13} \mathrm{C} /{ }^{12} \mathrm{C}$, and (d) ${ }^{13} \mathrm{C}^{15} \mathrm{~N}+{ }^{13} \mathrm{C}^{14} \mathrm{~N}$. (a) and (b) are the results of adding the counts from three successive sputter sections, (c) is the ratio between the two sets $\left({ }^{13} \mathrm{C}\right.$ and $\left.{ }^{12} \mathrm{C}\right)$ of three successive sputter sections, and $(\mathbf{d})$ is the three sputter sections of (a) plus the three of (b). The count numbers of $(\mathbf{a})$, (b) and (d), and the count ratio of (c) are given on the linear color scales.

detect in Figure 1c using the ratio of the ${ }^{13} \mathrm{C}^{-}$and ${ }^{12} \mathrm{C}^{-}$ions). Another way to decide whether ${ }^{13} \mathrm{C}^{14} \mathrm{~N}$ can be used for imaging when DNA is labeled with just ${ }^{13} \mathrm{C}$ is to add the counts from both ${ }^{13} \mathrm{C}^{14} \mathrm{~N}$ and ${ }^{13} \mathrm{C}^{15} \mathrm{~N}$ by combining the results in Figure $1 \mathrm{a} \& 1 \mathrm{~b}$ so as to increase the counts of ${ }^{13} \mathrm{C}$ (Figure 1d). This shows that the fibers can indeed be discerned (although it should be noted that here both strands are labeled rather than just one strand being labeled as would occur after a short pulse). This result is significant because it means that, in the same experiment, one could label the DNA successively: first with ${ }^{13} \mathrm{C}$ in ${ }^{14} \mathrm{~N}$ medium to detect ${ }^{13} \mathrm{C}^{14} \mathrm{~N}$ and then with ${ }^{15} \mathrm{~N}$ addition to detect ${ }^{13} \mathrm{C}^{15} \mathrm{~N}$. One might even succeed in detecting three consecutive sequences, for example, by (1) labeling with ${ }^{13} \mathrm{C}$ (via $\mathrm{U}^{-13} \mathrm{C}$-Glc) to detect the ${ }^{12} \mathrm{C}^{13} \mathrm{C}^{-}$or ${ }^{13} \mathrm{C}^{13} \mathrm{C}^{-}$recombinant ion (or indeed simply the ${ }^{12} \mathrm{C}^{-}$and ${ }^{13} \mathrm{C}^{-}$ions), then by (2) labeling with ${ }^{15} \mathrm{~N}$ (via ${ }^{15} \mathrm{NH}_{4} \mathrm{Cl}$ ) to detect ${ }^{13} \mathrm{C}^{15} \mathrm{~N}$, and finally by (3) replacing either the ${ }^{13} \mathrm{C}$ with ${ }^{12} \mathrm{C}$ (via U- ${ }^{12} \mathrm{C}-\mathrm{Glc}$ ) to detect ${ }^{12} \mathrm{C}^{15} \mathrm{~N}$ or the ${ }^{15} \mathrm{~N}$ with ${ }^{14} \mathrm{~N}$ (via
${ }^{14} \mathrm{NH}_{4} \mathrm{Cl}$ ) to detect ${ }^{13} \mathrm{C}^{14} \mathrm{~N}$. Such consecutive labeling would allow investigation of local variations in the velocities of replication.

In principle, CIS could permit testing of several hypotheses. These include (1) the idea that the elongation step of DNA replication is coupled to central carbon metabolism ${ }^{17-19}$ and that this changes the local structure of the DNA ${ }^{20,21}$ or changes the relative copy numbers of genes ${ }^{4}$ and thereby affects the phenotype, (2) the idea that the strand separation resulting from ion decondensation is responsible for the initiation of DNA replication ${ }^{22}$, (3) the idea that the time to rereplicate the chromosomes in a cell population growing in steady state is highly variable since these populations are phenotypically diverse $\mathrm{e}^{23,24}$, (4) the idea that the replication of a particular species of bacteriophages or viruses is very diverse. CIS could also be used to study the fine-scale interaction between DNA sequences and RNA, proteins and polyamines. Finally, CIS might eventually be 
used to study the modification of individual DNA fibers due to the covalent addition of methyl and acetyl groups, sugars, and other molecules, always providing that these molecules could either be labeled specifically by very rare isotopes such as ${ }^{14} \mathrm{C}$ or bound specifically by antibodies or aptamers that were themselves labeled.

The value of such potential applications of CIS depends on the number of different ions that can be detected and on the quality of this detection (which depends on factors such as the signal: background ratios, the dwell time, the intensity of the primary beam, and the use of serial sputter sections). With the latest NanoSIMS 50L version of the NanoSIMS range, seven different masses can be detected simultaneously in the acquisition of a single "sputter scan' ${ }^{25}$, which increases the numbers of carbon multi-clusters that can be analyzed. Finally, the quality of detection of ${ }^{13} \mathrm{C}^{-}$and the recombinant ${ }^{13} \mathrm{CN}^{-}$ions could be improved by coating the silicon surface with carbon depleted in ${ }^{13} \mathrm{C}$. In principle, therefore, CIS could distinguish between DNA labeled so as to give consecutive stretches enriched in $(1){ }^{13} \mathrm{C}$ (detectable as ${ }^{13} \mathrm{C}^{13} \mathrm{C}$ ), then (2) ${ }^{13} \mathrm{C}$ and ${ }^{15} \mathrm{~N}$ (detectable as ${ }^{13} \mathrm{C}^{15} \mathrm{~N}$ ) and, finally, (3) ${ }^{12} \mathrm{C}$ (detectable as ${ }^{12} \mathrm{C}^{15} \mathrm{~N}$ ) (note there are other possible combinations). CIS could, of course, be extended further still if the DNA were labeled with $\mathrm{Br}$ or I or even ${ }^{14} \mathrm{C}^{26}$.

\section{Conclusion}

CIS combines the advantages of DNA combing and SIMS in providing high sensitivity and high resolution since DNA fragments down to $1500 \mathrm{~nm}$ can be imaged at a resolution of $50 \mathrm{~nm}$. Moreover, the labeling with stable isotopes does not significantly perturb cells. The fact that CIS can detect ${ }^{13} \mathrm{C}^{14} \mathrm{~N}$ increases the number of separate labels available to the technique, thereby making CIS particularly valuable for studying phenotypically important variations in the elongation of DNA replication, as well as the processes of initiation of replication, recombination and repair. The increase in the repertoire of labels available to CIS also supports the case for it being adapted to study the interaction between DNA and other molecules, including proteins and drugs, and perhaps even to the precise localization of covalent modifications to DNA.

\section{Data availability}

F1000Research: Dataset 1. Raw data for Combing-Imaging by SIMS of bacterial DNA, 10.5256/f1000research.8361.d12027827

\section{Author contributions}

VN had the initial idea. AC, AFM, YC, JNA, DG, TW and LJ performed experiments. All authors participated in the data analysis and the writing of the paper.

\section{Competing interests}

The Luxembourg Institute of Science and Technology markets cesium-flooding equipment. Genomic Vision offers a DNAcombing service.

\section{Grant information}

This work was partly supported by the FP7 EU Network of Excellence, Nanobeams n`500440 to Henri-Noël Migeon.

The funders had no role in study design, data collection and analysis, decision to publish, or preparation of the manuscript.

\section{Acknowledgements}

We thank Stephane Alexandre for help with Atomic Force Microscopy.
1. Guerquin-Kern JL, Wu TD, Quintana C, et al.: Progress in analytical imaging of the cell by dynamic secondary ion mass spectrometry (SIMS microscopy). Biochim Biophys Acta. 2005; 1724(3): 228-238. PubMed Abstract | Publisher Full Text

2. Boxer SG, Kraft ML, Weber PK: Advances in imaging secondary ion mass spectrometry for biological samples. Annu Rev Biophys. 2009; 38: 53-74. PubMed Abstract | Publisher Full Text

3. Cabin-Flaman A, Monnier AF, Coffinier $\mathrm{Y}$, et al:: Combed single DNA molecules imaged by secondary ion mass spectrometry. Anal Chem. 2011; 83(18): 6940-6947.

PubMed Abstract | Publisher Full Text

4. Norris $V$, Jannière L, Amar P: Hypothesis: Variations in the rate of DNA replication determine the phenotype of daughter cells. In Modelling complex biological systems in the context of genomics. Evry, France. EDP Sciences, 2007; 71-81. Reference Source

5. Denapoli J, Tehranchi AK, Wang JD: Dose-dependent reduction of replication elongation rate by (p)ppGpp in Escherichia coli and Bacillus subtilis. Mol Microbiol. 2013; 88(1): 93-104.

PubMed Abstract | Publisher Full Text | Free Full Text

6. Maduike NZ, Tehranchi AK, Wang JD, et al:: Replication of the Escherichia coli chromosome in RNase HI-deficient cells: multiple initiation regions and fork dynamics. Mol Microbiol. 2014; 91(1): 39-56.

PubMed Abstract | Publisher Full Text | Free Full Text

7. Tan KW, Pham TM, Furukohri A, et al:: Recombinase and translesion DNA polymerase decrease the speed of replication fork progression during the DNA damage response in Escherichia coli cells. Nucleic Acids Res. 2015; 43(3): 1714-1725.

PubMed Abstract | Publisher Full Text | Free Full Text
8. Breier AM, Weier HU, Cozzarelli NR: Independence of replisomes in Escherichia coli chromosomal replication. Proc Natl Acad Sci U S A. 2005; 102(11): 3942-3947.

PubMed Abstract | Publisher Full Text | Free Full Text

9. Boukherroub R, Bensebaa F, Morin S, et al:: New synthetic routes to alkyl monolayers on the Si(111) surface. Langmuir. 1999; 15(11): 3831-3835. Publisher Full Text

10. Bensimon A, Simon A, Chiffaudel A, et al.: Alignment and sensitive detection of DNA by a moving interface. Science. 1994; 265(5181): 2096-2098. PubMed Abstract | Publisher Full Text

11. Michalet $\mathrm{X}$, Ekong R, Fougerousse $\mathrm{F}$, et al:: Dynamic molecular combing: stretching the whole human genome for high-resolution studies. Science. 1997; 277(5331): 1518-1523. PubMed Abstract | Publisher Full Text

12. Audinot JN, Cabin-Flaman A, Philipp P, et al.: NanoSIMS50 imaging of thin samples coupled with neutral cesium deposition. Surf Interface Anal. 2011; 43(1-2): 302-305 Publisher Full Text

13. Wirtz T, Migeon HN: Useful yields of MCsx+ clusters: A cesium concentrationdependent study on the Cation Mass Spectrometer (CMS). Applied Surface Science. 2004; 231-232C: 940-944.

14. Wirtz T, Migeon HN: Optimization of SIMS analyses performed in the MCs ${ }_{+}^{+}$ mode by using an in situ deposition of neutral Cs. Surf Sci. 2004; $557(1-3)$ : 57-72. Publisher Full Text

15. Legent G, Delaune A, Norris V, et al:: Method for macromolecular colocalization using atomic recombination in dynamic SIMS. J Phys Chem B. 2008; 112(17): 
$5534-5546$.

PubMed Abstract | Publisher Full Text

16. McMahon G, Glassner BJ, Lechene CP: Quantitative imaging of cells with multiisotope imaging mass spectrometry (MIMS)-Nanoautography with stable isotope tracers. Appl Surf Sci. 2006; 252(19): 6895-6906. Publisher Full Text

17. Maciąg-Dorszyńska M, Ignatowska M, Jannière L, et al:: Mutations in central carbon metabolism genes suppress defects in nucleoid position and cell division of replication mutants in Escherichia coli. Gene. 2012; 503(1): 31-35. PubMed Abstract | Publisher Full Text

18. Barańska S, Glinkowska M, Herman-Antosiewicz A, et al.: Replicating DNA by cell factories: roles of central carbon metabolism and transcription in the control of DNA replication in microbes, and implications for understanding this process in human cells. Microb Cell Fact. 2013; 12: 55 PubMed Abstract | Publisher Full Text | Free Full Text

19. Konieczna A, Szczepańska A, Sawiuk K, et al.: Effects of partial silencing of genes coding for enzymes involved in glycolysis and tricarboxylic acid cycle on the enterance of human fibroblasts to the S phase. BMC Cell Biol. 2015; 16: 16. PubMed Abstract | Publisher Full Text | Free Full Text

20. Bryant JA, Sellars LE, Busby SJ, et al.: Chromosome position effects on gene expression in Escherichia coli K-12. Nucleic Acids Res. 2014; 42(18) 11383-11392.

PubMed Abstract | Publisher Full Text | Free Full Text
21. Gerganova V, Berger M, Zaldastanishvili E, et al.: Chromosomal position shift of a regulatory gene alters the bacterial phenotype. Nucleic Acids Res. 2015; 43(17): 8215-8226.

PubMed Abstract | Publisher Full Text | Free Full Text

22. Norris V, Amar P: Chromosome Replication in Escherichia coli: Life on the Scales. Life (Basel). 2012; 2(4): 286-312.

PubMed Abstract | Publisher Full Text | Free Full Text

23. Campos M, Surovtsev IV, Kato S, et al:: A constant size extension drives bacteria cell size homeostasis. Cell. 2014; 159(6): 1433-1446.

PubMed Abstract | Publisher Full Text | Free Full Text

24. Taheri-Araghi S, Bradde S, Sauls JT, et al:: Cell-size control and homeostasis in bacteria. Curr Biol. 2015; 25(3): 385-391.

PubMed Abstract | Publisher Full Text | Free Full Text

25. Sangely L, Boyer B, De Chambost E, et al:: New Developments in Mass Spectrometry. Secondary ion mass spectrometry. 2015; 3: 439-499.

26. Hindie E, Escaig F, Coulomb B, et al.: Rapid localization of carbon 14-labeled molecules in biological samples by ion mass microscopy. $J$ Histochem Cytochem. 1989; 37(2): 135-138.

PubMed Abstract | Publisher Full Text

27. Cabin-Flamand A, Monnier AF, Coffinier $Y$, et al.: Dataset 1 in: Combining combing and secondary ion mass spectrometry to study DNA on chips using ${ }^{13} \mathrm{C}$ and ${ }^{15} \mathrm{~N}$ labeling. F1000Research. 2016.

Data Source 


\section{Open Peer Review}

\section{Current Peer Review Status:}

\section{Version 1}

Reviewer Report 11 July 2016

https://doi.org/10.5256/f1000research.8991.r14893

(c) 2016 Adams F. This is an open access peer review report distributed under the terms of the Creative Commons Attribution License, which permits unrestricted use, distribution, and reproduction in any medium, provided the original work is properly cited.

\section{Freddy C. Adams}

Department of Chemistry, University of Antwerp, Antwerp, Belgium

The article is a well-written report on work concerning the use of the Cameca NanoSims50 instrument for imaging of DNA fibers immobilized on silicon substrates. The work is a follow-up of earlier papers on the same subject by the present consortium. It contains work that is original and of interest for the scientific community. It shows the value of potential applications of CombingImaging with SIMS (CIS) and leads the way to further work with this ultra-sensitive chemical imaging tool. I fully support its indexations.

Competing Interests: No competing interests were disclosed.

I confirm that I have read this submission and believe that I have an appropriate level of expertise to confirm that it is of an acceptable scientific standard.

Reviewer Report 27 June 2016

\section{https://doi.org/10.5256/f1000research.8991.r14618}

(C) 2016 Fabre B. This is an open access peer review report distributed under the terms of the Creative Commons Attribution License, which permits unrestricted use, distribution, and reproduction in any medium, provided the original work is properly cited.

\section{Bruno Fabre}

MaCSE Research Group, Institute Of Chemical Sciences Of Rennes, UMR CNRS 6226, University of Rennes 1, Rennes, France

This article provides significant insights in a novel SIMS imaging technique focusing on the imaging of DNA fibers immobilized on modified silicon surfaces. The conclusions are adequately supported by the experimental data. Consequently, I recommend indexation of this as is. 
Competing Interests: No competing interests were disclosed.

I confirm that I have read this submission and believe that I have an appropriate level of expertise to confirm that it is of an acceptable scientific standard.

The benefits of publishing with F1000Research:

- Your article is published within days, with no editorial bias

- You can publish traditional articles, null/negative results, case reports, data notes and more

- The peer review process is transparent and collaborative

- Your article is indexed in PubMed after passing peer review

- Dedicated customer support at every stage

For pre-submission enquiries, contact research@f1000.com 